\section{Rosa María Grillo}

Profesora titular de la Universidad de Salerno, donde alterna cursos y publicaciones de literatura española contemporánea con los de literatura hispanoamericana. Es autora de numerosos ensayos y monografías publicados en Italia, Francia, España y Uruguay. Sus trabajos que versan los intelectuales y el exilio español y sobre narrativa hispanoamericana del 900 (realismo mágico, novela histórica posmoderna, etc.); así como sobre escritores españoles e hispanoamericanos como Fernán Caballero, Juan Gil Albert, Rosa Chacel, José Bergamín, Max Aub, Rosa Montero, Horacio Quiroga, Mario Benedetti, etc.

\title{
TRES NOVELAS PARA LA MISMA HISTORIA: EL ENCUENTRO ENTRE CORTÉS Y XICOTÉNCATL
}

\author{
Rosa MARÍA GRILLO
}

En la primera mitad del siglo XIX una situación similar en Europa y América pudo facilitar la insurgencia de la novela histórica, en el momento de gran tensión productiva y afirmativa de la Modernidad en cuanto época de la dominante histórico-cultural burguesa, fundada en la fe en el progreso científico y tecnológico, en el proyecto histórico-político de la emancipación humana y en la certeza acerca de la superioridad absoluta del modelo cultural de Occidente ${ }^{1}$; además la Revolución francesa, las guerras napoleónicas y antinapoleónicas en Europa y las guerras de Independencia americanas favorecen el sentido de participación del pueblo en la idea de nación y abren el camino a la definitiva afirmación de la clase burguesa como clase dominante no sólo en lo económico y cultural sino también en lo político.

Este optimismo histórico en la suerte de Occidente inspira también a los intelectuales hispanoamericanos, marginales pero no extraños al mundo de la Modernidad europea, que a pesar de la reciente independencia y del sentimiento de rencor hacia la ex-madre patria, siguen sintiéndose parte de Occidente y confían en que sus propios males sean consecuencia de la mala administración colonial y que se podrán subsanar gracias a las nuevas formas de gobierno y a la labor de intelectuales y políticos.

Anulando por un momento toda distancia cronológica en el campo cultural entre América y Europa, se inaugura la moda romántica de buscar en el pasado los mitos, los héroes, las razones de una identidad nacional según la episteme de la clase burguesa. Y si en Europa la novela histórica pretendió crear una génesis y un pasado a la nueva clase en el poder buscando en la Edad Media el origen de las naciones burguesas que iban surgiendo, también la novela histórica latinoamericana surgió como expresión del proyecto político de la burguesía criolla según la línea trazada por Lukacs, a quien responde como un eco Noé $\mathrm{Jitrik}^{2}$ afirmando que, en el siglo XIX como en el XX, la novela histórica nace, se modifica y reubica como consecuencia de grandes cambios sociohistóricos por los cuales puede pasar de forma residual a emergente o viceversa: su tarea es la de revisionar el pasado confirmando o rectificando la versión oficial de la Historia según las nuevas categorías epistemológicas emergentes de estos cambios sociohistóricos ${ }^{3}$. No falta quien define «la nación mediante su producción textual (periódicos, historiografía, literatura, música, himnos nacionales, etc.) ${ }^{4} \mathrm{y}$ por eso se puede entender el gran afán de intelectuales criollos por producir una idea de nación proyectada hacia el futuro, desprendida de la historia colonial sentida como negativa. Realizada la Independencia política, hay que realizar «una cultura, una literatura, una gramática y una filosofía americanas $»^{5}$ que seleccionen del pasado el legado positivo y olviden lo demás:

las gestas libertadoras y algunos hechos del pasado colonial que las anticiparon, comenzaron a ser rescatados y ordenados en relación con un proyecto que 
implicaba, inevitablemente, el repudio de ciertos elementos valorativos que habían constituido el esquema axiológico de la colonia española, pero que no fue y no pudo ser nunca un rechazo total de los mismos ${ }^{6}$.

Naturalmente no se puede indicar una única episteme para toda la clase dirigente criolla latinoamericana: demasiadas son las diferencias entre las diversas regiones americanas (bastaría pensar en la repartición de Darcy Ribeiro en Pueblos testimonio, nuevos y trasplantados ${ }^{7}$ ) para teorizar un único modelo de 'origen de la nación' y de 'nación', una solución unívoca a los enfrentamientos entre Bien y Mal, Civilización y Barbarie, que sustentan la trama de cualquier mito fundacional, romance o novela histórica, oponiendo al héroe su contrario, idealizándolo y consignándole las últimas posibilidades de sentido épico en cuanto representante no de un destino individual sino de la sociedad entera ${ }^{8}$. Sería éste uno de los caracteres del romance en la terminología anglosajona y que podemos trasladar a la novela histórica: según Frye y más tarde Jameson', en estos textos la sociedad se representa en términos antinómicos cuyos ejes están determinados por los valores éticos de un determinado grupo o sociedad, valores éticos que no son sino la forma aparentemente universal y ahistórica que asume la ideología dominante, que en el momento en que configura a sus héroes necesita también fijar al enemigo como radicalmente diferente ('otro').

En líneas generales podemos estar de acuerdo con la tesis consagrada sobre la novela histórica latinoamericana, como la resume Haydee Ahumada Peña:

Ante un Romanticismo Hispanoamericano que ve en la literatura una expresión de la sociedad, expresión que integra al pueblo y trata de plasmar su idiosincrasia, su especificidad, la novela histórica, marcada por su propia contingencia, se integra a la función utilitaria asignada a la literatura, motivando el progreso social, guiando hacia una edificación política y revelando, en definitiva, ese signo progresivo que define el romanticismo propiamente americano ${ }^{10}$.

Por otra parte Andrés Bello, uno de los 'padres' de la identidad americana, en El repertorio americano (1826) confía al intelectual una tarea difícil y de gran responsabilidad: «establecer el culto de la moral; conservar los nombres y las condiciones que figuran en

nuestra historia; asignándoles un lugar en la memoria del tiempo». Y más directamente, afirma, al novelista «se le ha pedido no que [...] cuente aventuras de individuos, sino que [...] los muestre como testimonios verdaderos y animados de un país, de una época, de una opinión» ${ }^{11}$.

A estos cánones, pero con sustanciales diferencias de 'modelo' según las realidades etnogeográficas, corresponden la mayoría de novelas históricas latinoamericanas, desde la 'residual' epopeya de Zorrilla de San Martín a las novelas fundacionales de Acevedo Díaz, que tanto contribuyeron a la noción de identidad de un país joven y sin identidad como Uruguay. Sintiéndose más un pedazo desprendido de Europa que parte integrante del continente americano, la literatura del Río de la Plata, reflejando esta ideología coincidente con el imaginario colectivo, hasta en sus expresiones más progresistas e iluminadas reivindica su orgullosa filiación europea. Siendo el Río de la Plata 'pueblo trasplantado' por antonomasia según la acertada definición de Darcy Ribeiro, sin Historia autóctona, tenía que construir su propia historia y su propia imagen apelando a la historia y a la imagen europeas: el origen lo encuentra en la colonia, básicamente sin conflictos étnicos o bien resueltos en un mestizaje idílico o en la afirmación de una clase burguesa de simpatías y procedencia europeas. Así en Argentina el socialista Payró a principios del siglo XX escribió sobre el Descubrimiento y la Conquista unas novelas históricas asignando siempre el papel positivo a hombres blancos, portadores de civilización y progreso: por ejemplo en El mar dulce Francisco del Puerto, el primer poblador blanco del Río de la Plata, es indicado como

«Instrumento para convertir a esos salvajes [...], símbolo o vaticinio [...] tierno vástago de la estirpe secular, cautivo de los indios, quedaba a orillas del Mar Dulce donde reverdecería y crecería, como tronco apenas recordado de la primera anónima rama de

6 Arturo Andrés Roig, Teoría y crítica del pensamiento latinoamericano, México, FCE, 1981 , págs. $62-63$.
7

Cfr. Darcy Ribeiro, Configuraciones histórico culturales americanas, Montevideo, Arca/Calicanto, 1972
8

Así se dirigirá a Xicoténcatl, el héroe de las novelas que analizaremos más adelante, un antiguo enemigo suyo: "Tu patria no es ya Tlaxcala: la humanidad reclama tus servicios y un mundo entero te señala como a su libertador» (anónimo, Xicoténcatl, en La novela del México colonial, I ed. a cargo de Antonio Castro Leal, México, Aguilar, 1964 pág. 138).

9

Cfr. las interesantes consideraciones sobre el romance, la historia las fábulas fundacionales y la novela histórica de Fernando Unzueta, La imaginación histórica... op. cit., págs. 75-76 y 82-85.

10

Haydee Ahumada Peña, «Los talaveras de Liborio Brieba, subversión literaria en el discurso histórico», Revista Signos, Valparaíso, 1991, n. 30, pág. 4 .

11

Andrés Bello, «Modo de escribir la historia», en A.B., Obras completas, XXIII, Caracas, La Casa de Bello, 1981, pág. 236.
Tres novelas para la misma historia: el encuentro entre Cortés y Xicoténcatl

ROSA MARIAA GRILLO 


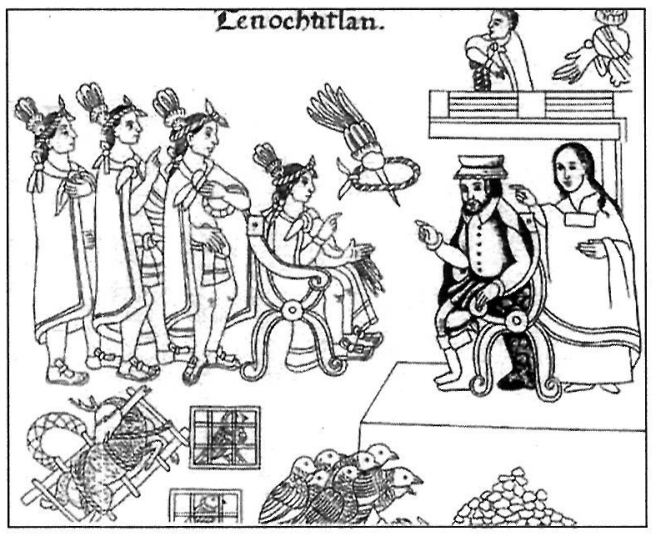

12

Roberto J. Payró, El mar dulce, Buenos Aires, Losada, 1974 págs. 214 y 219 . Cfr. mi «El viaje de Francisco del Puerto desde las crónicas a las novelas», Cuadernos de Thule, Perugia, 2003, n. 2, págs. 215-222.

\section{3}

En esto no estoy de acuerdo con el por otros versos excelente trabajo de Fernando Unzueta cuando afirma que «el 'Otro' del proyecto liberal eran la 'barbarie' $y$ el 'retroceso'; o, en otros términos, los indígenas y los grupos subalternos en general, como lo prehispánico, el pasado colonial español, $y$ todo aquello alejado de la Modernidad europea-norteamericana" (Fernando Unzueta, La imaginación histórica...op cit., pág. 23). Yo creo que se necesita matizar más este concepto, a partir de la región de origen del autor y de la región en que se desarrolla la novela, así como del preciso momento histórico en que vive el autor.

14

Peter Elmore, La fábrica de la memoria, México, FCE, 1997, pág. 11.

15

Ibidem, pág. 28.

16

Ibidem, págs. 39-40. Este carácter, ya presente en numerosas novelas históricas latinoamericanas desde sus orígenes, en las literaturas europeas del siglo XX se ha interpretado como propio de la posmodernidad.

Tres novelas para la misma historia: el encuentro entre Cortés y Xicoténcatl

ROSA MARÍA GRILLO logía del héroe ${ }^{13}$.

criollos del Río de la Plata. Realización de un sueño en forma no soñada, sus descendientes habían de ver que las pobres tierras de desengaño escondían en realidad tesoros inagotables, más perennes que el oro y que la plata ${ }^{12}$.

En cambio, donde las culturas azteca, maya e inca han 'resistido' al aluvión destructor del conquistador primero, del colonizador luego, y han mantenido 'reservas' de su propia cultura ('pueblos testimonio'), o donde hubo una amalgama antigua y profunda también con las etnias africanas dando un resultado completamente nuevo ('pueblos nuevos'), de doble o triple mestizaje si no de sangre, seguramente de cultura, no puede existir un modelo unívoco: aun siendo los intelectuales, escritores y artistas en su gran mayoría étnica y culturalmente 'europeos', no pueden desconocer la 'otra cara' de su identidad y por lo tanto eligen a menudo como figuras emblemáticas de los momentos fundacionales a personajes inquietantes, ambiguos o al revés, cabal y dramáticamente resueltos, decididos, épicos, con una diversificada tipo-

La elección del momento histórico de la Conquista como tema privilegiado responde a la exigencia propia de la novela histórica ya que «el comienzo de la experiencia colonial en los siglos XV y XVI y la fundación de estados autónomos en el XIX pueden ser vistos como momentos de fisura, procesos dramáticos en los cuales se condensan las contradicciones que marcan a las sociedades latinoamericanas» ${ }^{14}$. Es el momento del choque dramático entre dos mundos, entre tiempos y culturas diferentes, y por lo tanto el carácter dramático de la Historia se impone con mayor evidencia: «los héroes representativos de una época -es decir, esos individuos universales

17

Se le conoce con muchos nombres, Xicontécatl, Jicontécatl, Xicoténcatl, Jicoténcatl, Xicotenga, Sicutengal.

18

En la segunda mitad del siglo XIX también la historiografía que marcan el tránsito hacia un nuevo ordenson figuras esencialmente trágicas» ${ }^{15}$, aún más en los casos que vamos a analizar, donde el héroe pertenece al mundo de los vencidos, y por lo tanto fatal y trágicamente predestinado al fracaso. En buena parte de las novelas históricas latinoamericanas -sobre todo en las regiones donde la presencia indígena es numérica y cualitativamente relevante-, al contrario de lo que pasa generalmente en las europeas,

el impulso retrospectivo no aspira a convertir al principio en el lugar del sentido pleno, en el sitio donde los enigmas de la Comunidad y el Estado se esclarecen; por lo contrario, lo que caracteriza a los ejemplos más notables del género es la crítica a los orígenes de la nacionalidad, el desmantelamiento de los mitos patrióticos. En el espacio de los relatos, la duda trágica y el distanciamiento irónico corroen e interrogan a los tópicos consagrados por la tradición y los aparatos del Estado; al mismo tiempo, el ejercicio de la relectura pone en relieve el carácter textual, ideológico, de las imágenes hegemónicas del pasado colectivo ${ }^{16}$.

Este punto me parece muy importante ya que la novela histórica latinoamericana es expresión de la episteme de la clase burguesa criolla llegada al poder con las guerras de Independencia, clase criolla que fue parte dirigente del sistema colonial a la vez que su liquidador, poder periférico respecto al centro metropolitano pero centro respecto a la periferia local (léase indígenas, negros, etc.). A lo problemático de esta situación se debe la variedad de lecturas que han suscitado algunos episodios de la Conquista como, en el caso mexicano, el enfrentamiento Xicoténcat ${ }^{17}$ - Cortés. En el gran enigma histórico de la Conquista de México, éste es un evento repetidamente recreado a lo largo de la historia literaria, con variantes interpretativas claramente dependientes del momento histórico, de la procedencia e ideología del escritor, de la clave usada para interpretar y juzgar aquel momento fundacional de la historia mexicana y centroamericana: la época fúlgida del imperio español y su 'exportación' a las Américas, o la oscura de la traición y el genocidio, según el punto de vista ${ }^{18}$. Sin tergiversar la Historia oficial, sólo interpretándola y acompañándola con la historia familiar, se puede cambiar el discurso, es decir la evaluación de los acontecimientos. Como escribió Vicente Fidel López, 
como la verdad es que al lado de la vida histórica ha existido la vida familiar, así como todo hombre que ha dejado recuerdos ha tenido un rostro, el novelista hábil puede reproducir con su imaginación la parte perdida creando libremente la vida familiar y sujetándose estrictamente a la vida bistórica en las combinaciones que haga de una y otra para reproducir la verdad completa ${ }^{19}$.

A continuación analizaremos tres novelas publicadas en un arco de tiempo restringido (1826-1870) que proponen, utilizando las mismas fuentes y no tergiversándolas, entramando vida histórica y vida familiar, discursos diferentes y diferentes modelos de nación y de identidad nacional.

Mientras que la figura de Moctezuma el Joven constituye un enigma histórico al cual se han dedicado múltiples ensayos y monografías, de exaltación o de reproche, el general tlaxcalteca Xicoténcatl apareció en el siglo XIX como el héroe sin mancha, el héroe épico que va hacia su destino sin titubeos: lo que el nuevo México mestizo y antiespañol estaba buscando para fundamentar su propia identidad en el mito de la nobleza precolombina. Por otra parte, Cortés es el medio providencial que hace posible la conquista, la civilización y la conversión de los indígenas; pero es también el iniciador y el representante de aquel sistema colonial cuyo único fin fue el de depredar, saquear, oprimir la colonia en nombre de la metrópolis.

A pesar de diferentes interpretaciones de hechos específicos, los cronistas e historiadores españoles del tiempo coinciden en indicar a los tlaxcaltecas como "muy capitales enemigos de Mutezuma [...] y que tenían con él muy continuas guerras» ${ }^{20}$, y en reconocer el coraje de Xicoténcatl el Joven, el único que opone una visión realista y pragmática a la fatalista y regida por los presagios y tradiciones de su mismo padre y de Moctezuma. Caracteres negativos le atribuye sólo Bernal Díaz del Castillo, que lo define «de mala condición, porfiado y soberbio» ${ }^{21}$.

La historia es conocida: los cuatro jefes de Tlaxcala, entre los cuales Xicoténcatl el Viejo, deciden dejar pasar por sus tierras al invasor, camino hacia Tenochtitlan; sólo Xicoténcatl el Joven se opone, lucha, ataca a los españoles: «y Xicotenga [...] siempre nos seguía, y faltaban ya sobre cuarenta y cinco soldados que se habían muerto en las batallas [...] Era ese Xi- cotenga alto de cuerpo y grande de espalda y bien hecho, y la cara tenía larga y como hoyosa y robusta: $y$ era de hasta treinta $y$ cinco años, y en el parecer mostraba en su persona gravedad $\gg^{22}$. No pudiendo con la fuerza, Cortés recurre a la palabra y a la astucia, envía mensajeros convenciendo a los viejos sabios tlaxcaltecas de que

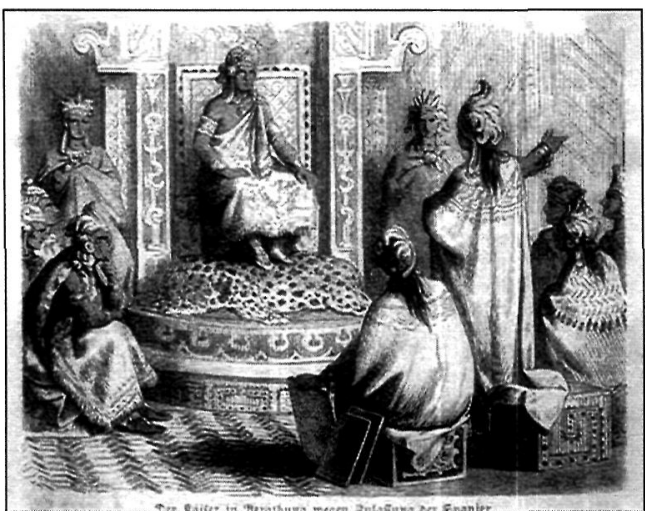

Xicotencat los españoles son enemigos de Moctezuma, y que los liberarán para siempre de impuestos y servidumbres al gran emperador: «con los unos y con los otros maneaba y a cada uno en secreto le agradecía el aviso que me daba, y le daba crédito de más amistad que al otro» ${ }^{23}$. Se firma la paz y Xicoténcatl el Joven acepta las decisiones del Senado: en su calidad de jefe militar guía al ejército que acompaña a Cortés en su viaje hacia Tenochtitlan, pero por causas dudosas ${ }^{24}$ se «ausentó secretamente del ejército y tomó en compañía de algunos otros el camino de su patria». Capturado por los españoles, fue ahorcado públicamente por «haberse desertado y haber procurado conmover a los tlaxcaltecas contra los españoles [...] Se halló en él porfiada resistencia» ${ }^{25}$. Es muy útil cotejar esa Historia antigua de México del jesuita Francisco Javier Clavijero con las novelas históricas sobre el tema porque con su moderna técnica historiográfica y los muchos textos que tuvo a su alcance pudo escribir la 'primera historia de México' confrontando diferentes versiones e interpretaciones, añadiendo a la simple descripción de un hecho notas a pie de páginas, versiones contrastantes, interrogaciones y dudas. Además «la estima que tenía a los indígenas», el haber nacido y vivido en Veracruz en contacto fecundo «con los indígenas súbditos de su padre» aprendiendo sus lenguas (náhuatl, otomí y mixteca), el conocer el terreno (corrige a menudo errores geográficos sobre todo de Solís), el haber estudiado en los colegios jesuitas y por fin, el haber vivido exiliado en Ferrara y Bolonia y haber podido frecuentar bibliotecas e intelectuales italianos, fueron concausas felices para que escribiera la Historia antigua de México (1779): «más que autor de la historia de México, debe llamarse su creador. Había miles de fragmentos utiliza-
19

Vicente Fidel López, «Carta-Prólogo» a V.F.L., La novia del hereje, Buenos Aires, Cultura argentina, 1917, pág. 19.

20

Hernán Cortés, "Segunda Carta», en H.C., Cartas de Relación, ed. al cuidado de Maria Vittoria Calvi, Milano, Cisalpino-La Goliardica, 1988, pág. 114.

21 verdadera de la conquista de la Nueva España, cap. LXX, ed. al cuidado de Carmelo Sáenz de Santa María, México, Patria, 1983, pág. 182.

22

Ibidem, cap. LXXIII, pág. 189

23

Hernán Cortés, «Segunda carta», op, cit., pág. 124.

\section{4}

Clavijero propone tres interpretaciones: por la herida hecha por un soldado español a un primo suyo, o bien «por apoderarse, en la ausencia de Chichimécatl, de sus estados; pero esto es del todo inverosímil. No falta quien diga que lo llevó a Tlaxcala el amor a una dama» (Francisco Javier Clavijero, Historia antigua de México, México, Porrúa, 1982, pág. 396).

\section{5}

Ibidem.

Tres novelas para la misma historia: el encuentro entre

Cortés y Xicoténcatl

ROSA MARÍA GRILLO
Bernal Díaz del Castillo, Historia 
Mariano Cuevas, «Prólogo» a Francisco Javier Clavijero, Historia antigua de México, op. cit., pág. XII (el prólogo es de 1944).

\section{7}

Imprenta Guillermo Stavely, en dos volúmenes de pequeño tamaño de 224 y 247 páginas. En aquella época Filadelfia, que había sido en 1778 sede de las Convenciones de la Independencia, era un importante centro cultural progresista y había sido lugar de encuentros para muchos patriotas hispanoamericanos (cfr. Antonio Castro Leal, «Prólogo» a Xicoténcatl, en La novela del México colonial, op. cit., pág. 79. Este texto contiene un prólogo general, págs.11-28, y uno específico, págs. 83-86. En adelante, el número de página entre paréntesis en el texto se refiere a esta edición!

\section{8}

En realidad son dos obras distintas, con un fítulo parecido, publicada una en Filadelfia (Jicoténcal, 1826) y otra en Valencia de España (Xicotencatl, príncipe americano, 1831). Esta última es de Salvador García Bahamonde (cfr. Reginald F. Brown, La novela española 1700-1850, Madrid, Biblioteca de Archivos y Bibliotecas, Ministerio de Educación Nacional, 1953, pág. 81). La primera ha sido atribuida a Varela por Luis Leal, y a Heredia por González Acosto (cfr. Alejandro González Acosta, El enigma de Jicotencal, op. cit, y mi «La otra historia de la Conquista de México: Xicoténcafl (1826)», en prensa en La ruta de la obsidiana. Percorsi mesoamericani, Actas del Congreso de Salerno (dic. 2002). En esta ocasión lo que me interesa no es confrontar una visión americana a una española -confrontación sin duda iluminadora ya que se trata de dos textos voceros de bandos opuestos-, sino tres interpretaciones americanas sobre el mismo tema que expresan tres lecturas diferentes de la Conquista.

29

Antonio Castro Leal, «Prólogo» a Xicoténcatl, op. cit., pág. 83. Sigo la grafía y la edición de Castro Leal.

Tres novelas para la misma historia: el encuentro entre Cortés y Xicoténcatl

ROSA MARIA GRILLO

bles para esa gigantesca construcción, pero obra de consunto, de partes bien trabadas y unidas, no había ninguna ${ }^{26}$. Ya en esta historia del siglo XVIII, 'creada' por su autor en cuanto discurso colonial coherente y dirigida a la edificación de una identidad, encontramos in nuce muchos elementos que serán desarrollados en las novelas posteriores, y por su oferta al lector de diversas interpretaciones y posibilidades se pone como texto historiográfico moderno e intrigante.

La re-creación ficcional de este episodio empezó con Xicoténcatl, publicado anónimo en 1826 en Filadelfia ${ }^{27}$, atribuida ahora al español Salvador García Bahamonde, ahora al cubano Félix Varela, ahora al cubano-mexicano José María Herediaa ${ }^{28}$. Como subraya Antonio Castro Leal, parece improbable que sea obra de un español ya que «además de que revela una sincera simpatía hacia la causa de los indios, los juicios que contiene sobre España y los conquistadores españoles son denigrantes y francamente hostiles» ${ }^{29}$. Sin entrar en este debate, y asumiéndola como de autor americano, posiblemente un mexicano exiliado en Estados Unidos, considero esta novela una excelente muestra del discurso poscolonial ${ }^{30}$, en cuanto el héroe positivo, Xicoténcatl, tanto en la vida familiar como en la vida bistórica, es la summa de valores humanos, civiles y guerreros y se impone como 'testimonio verdadero y animado de un país, de una época, de una opinión', según la definición de Andrés Bello, en contraposición a Cortés, a su vez summa de todos los anti-valores correspondientes. Y hablo de postura poscolonial en su sentido más estricto y más profundo -cronológica e ideológicamente- que raramente se encuentra en otras obras hispanoamericanas del siglo XIX, en las que la

30

En otra ocasión me he ocupado de la imposibilidad de incluir Latinoamérica tanto dentro del conjunto de los países posmodernos como de los pos coloniales sin oportunas distin ciones y correcciones / $\ll$ Feminismo y poscolonialismo en Ella escribía poscrítica de Margarita Mateo», en Antonio Melis y Domenico Antonio Cusato (eds.),... las palabras se unieron como plumas... Homenaje a Hernán Loyola, Messina, Andrea Lippolis, 2002, págs. 159-178).
31

Vicente Fidel López, La novia del hereje, op. cit., pág. 299

\section{2}

Vicente Fidel López, «Carta Prólogo», ibidem, pág. 17.

33

No deja de maravillar el hecho de que, a pesar de esta fidelidad textual, se invierten puntualmente los juicios políticos $y$ morales de Solis así como sus incipientes retratos o deducciones psicológicas, de los que su texto abunda. oposición será privilegiadamente entre criollos y representantes del poder central, o entre españoles 'buenos' y españoles 'malos', o entre criollos 'buenos' y criollos 'malos'.

En este sentido, y de forma más cabal que en otras novelas, Xicoténcatl aparece como el héroe de una epopeya moderna, con el presentimiento del inevitable fracaso, casi la última posibilidad que ha dado la Historia antes de la degradación y falta de totalidad de la época moderna. México y su literatura son las pruebas más contundentes de que en aquellas tierras el pasado no puede ser simplemente ni el pasado europeo ni el americano precolombino, sino que hay que crearlo a la medida de la población y de su imaginario y que en su creación a menudo es difícil separar un precoz pro-indigenismo del rencor antiespañol que exige la búsqueda del héroe entre los enemigos de España. En otras latitudes, como por ejemplo en La novia del hereje (1854) del argentino Vicente Fidel López, a falta de héroes indígenas, la función antiespañola la ejercen Francis Drake y su gente: el 'pirata' violento y despiadado de la historiografía española es, en la historiografía inglesa y en la obra del argentino, el autor de «gigantescas hazañas, como gloriosos pasos de la humanidad en el camino de la civilización y del conocimiento del globo» ${ }^{31}$, en oposición a la lucha que la «raza española sostenía en el tiempo de la conquista, contra las novedades que agitaban al mundo cristiano y preparaban los nuevos rasgos de la civilización actual» ${ }^{32}$. Así, a veces sólo en oposición a la Conquista, se insinúa lo 'otro', esta faceta de la historia americana que condenando rotundamente modos y protagonistas de la Conquista española estorba las ideas de progreso lineal y de superioridad de la cultura occidental burguesa, que también en Latinoamérica confiaba a la novela histórica un papel importante en la construcción de una sociedad moderna según el modelo europeo y norteamericano.

Es verdad que muchos párrafos de Xicoténcatl están tomados al pie de la letra de la Historia de la Conquista de México de Solís, entrecomillados como testimonio de fidelidad a la Historia ${ }^{33}$ (y en menor medida de Bartolomé de las Casas y Clavijero), pero es en la elección y concatenación de los hechos y en la interpretación de sus motivaciones, además que en la vida familiar que se desarrolla paralelamente a la vida histórica, que se explicita el discurso interpretativo del entero aconteci- 
miento. Muestra de gran modernidad y 'diversidad' es la puesta en discusión de la Verdad de la Historia y de la necesidad de re-escribirla según la visión de los vencidos, cosa que parece adelantar de más de un siglo las propuestas historiográficas del poscolonialismo:

En vano los historiadores intentan encubrir la negra infamia con que se cargó para siempre aquel insolente y astuto cuanto afortunado capitán; en vano el vértigo monárquico que ha embrutecido por tantos tiempos a Europa nos ha privado de los documentos históricos más preciosos sobre la república de Tlaxcala. El ojo perspicaz del filósofo sabe distinguir, entre el fango y basura que ensucian el papel de las historias, algunas chispas de verdad que no han podido apagar ni el fanatismo ni la servil adulación ${ }^{34}$.

Es verdad que este planteamiento no es exclusivo del autor de Xicoténcatl, más bien será común a muchos escritores de novelas históricas en los años siguientes, pero me parece que aquí con más claridad se impone una visión realmente alternativa a la Historia oficial adoptando el punto de vista 'político' de los indígenas: en otros casos, más bien podemos hablar de alternativas en el interior de la visión de los vencedores, como podría ser la versión 'criolla' opuesta a la versión metropolitana o la versión de los patriotas liberales a la versión hispanófila de los conservadores (como sería el caso de Soledad de Bartolomé Mitre) $)^{35}$.

El anónimo autor exalta los ideales republicanos que parecen concretarse en Tlaxcala que lucha contra el tirano:

por todas partes se dejaba ver la igualdad que formaba el espíritu público del país [...] Su gobierno era una república confederada; el poder soberano residía en un congreso o senado, compuesto de miembros elegidos uno por cada partido de los que contenía la república [...] El espíritu nacional de los tlaxcaltecas era tan decidido que [...] se sostuvieron siempre en guerra contra aquel emperador poderoso, y siempre invencibles ${ }^{36}$ (pág. 88).

Así «Tlaxcala se configura como lugar utópico, incontaminado, cerrado al comercio del oro y de la plata» ${ }^{37}$, que sucumbirá sólo delante de la traición y el engaño. Entre todos los tlaxcaltecas, sobresale el joven general «Xicoténcatl [que] por sus talentos militares, sus buenas prendas y su puro y desinteresado patriotismo, obtuvo, aunque tan joven, la preferencia sobre los demás candidatos» (pág. 88). Hasta un antiguo enemigo ie reconoce esos méritos, ampliando su 'misión' de resistencia a Cortés a nivel continental: «Tú tienes un ejército que te respeta y te ama por tus virtudes y por tu valor: Tu patria no es ya Tlaxcala; la humanidad reclama tus servicios y un mundo entero te señala como a su libertador» (pág. 138). Me parecen esas palabras muy 'americanas' y muy datadas: estos años, ya consumada la Independencia, ven la lucha entre federativos y unitarios, y precisamente en 1826 los estados americanos recientemente formados se reunieron en Panamá, convocados por Bolívar, para intentar fomentar la unidad continental: ¿no podría ser esta descripción de Tlaxcala un modelo de confederación en el cual inspirarse los americanos en el momento de decidir el futuro de las jóvenes repúblicas, inciertos entre confederaciones más amplias o naciones independientes, y siempre acosadas por soluciones fuertes e individualistas? Intentando defenderse de los conatos dictatoriales post-independencia buscan en $\mathrm{Xi}$ coténcatl el símbolo de «un alma republicana [que] cual otro Bruto, juró la muerte del tirano» (pág. 159). Estas comparaciones con el mundo europeo antiguo, en un contexto profundamente eurocéntrico como era la sociedad americana, confirman la voluntad del autor de subrayar las altas cualidades humanas y civiles 'universales' del héroe, y de alguna forma borrar la diferencia entre las dos culturas, sentida siempre como relación inferioridad /superioridad.

Al modelo republicano y al héroe Xicoténcatl el anónimo autor opone el sistema piramidal del Imperio español y el astuto Cortés, quien «no supo jamás lo que era miedo ni temor» (pág. 108) pero utilizaba estas virtudes para su insaciable ambición. Con gran habilidad desde el principio el autor insinúa las capacidades políticas de Cortés («le dio la mano con apariencias de grande amistad», pág. 112), luego subraya su crueldad y su doblez, su capacidad maquiavélica para volver a su provecho cualquier circunstancia. En esto respeta la imagen ya consagrada de Cortés de hombre renacentista que elige la razón como eje de conocimiento y comportamiento, separando la ética de la política: como ha escrito Henry R. Wagner, «aunque Cortés no imitase a César
34

Xicoténcatl, op. cit., pág. 169.

35

A estos casos parece referirse $\mathrm{Vi}$ cente Fidel López: «Así nacen las diversas escuelas de la historia social, es decir, la diversa inclinación que muestra cada época o cada grupo de escritores, a hacer que tales o cuales impulsos especiales de la humanidad dominen la narración y expliquen todos los acontecimientos que entran en ella, olvidando necesariamente otros no menos importantes, por cierto, y que, adoptados por otro grupo de escritores, incompletos también, son, a su vez, ofrecidos como la sola luz que aclara e abismo donde moran y se enredan las causas de nuestras acciones y el secreto completo de los trastornos sociales [...] En la manera de explicarlos, asignándoles causas y efectos, es donde están el misterio, las dificultades, las variedades y contradicciones de la historia» (Vicente Fidel López, La novia del hereje, op. cit., pág. 114).

36

Este carácter despierta el respeto de Cortés, aunque podemos recordar que elogiar a unos enemigos invictos ensalza aún más los méritos del conquistador: «siempre se habían defendido contra el gran poder de Mutezuma y de su padre y abuelos, que toda la tierra tenían sojuzgada y a ellos jamás habian podido traer a sujeción, teniéndolos como los tenían cercados por todas partes sin tener lugar para por ninguna de su tierra poder salir [...] y que todo lo sufrían y habían por bueno por ser exentos y no sujetos a nadie [...] La orden que hasta ahora se ha alcanzado que la gente de ella tiene en gobernarse, es casi como las señorías de Venecia y Genova o Pisa, porque no hay señor general de todos》 (Hernán Cortés, "Segunda Carta», op. cit., págs. 120-121).

\section{7}

Silvia Benso, «Xicoténcatl: para una representación del pasado Haxcalteca», Romanticismo, n. 34, Actas del IV Congreso sobre el romanticismo español e hispanoamericano, Genova, Testi Universitari, 2000, pág. 146.

Tres novelas para la misma historia: el encuentro entre

Cortés y Xicoténcatl

ROSA MARÍA GRILLO 
Cfr. Beatriz Pastor, Discurso narrativo de la conquista de América, La Habana, Casa de las Américas, 1983, pág. 190.

\section{9}

Antonio Castro Leal, "Prólogo» a Xicoténcall, op. cit., pág. 85.

40

En la ficción Xicoténcatl y Cortés se entrentan también en la vida familiar: Cortés aprisiona a Teutila, amada de Xicoténcatl, e intenta seducirla. Quizás la parte más débil de la obra sea precisamente el juego de pasiones $y$ equivocaciones amorosas alrededor de este triángulo: Ordaz ama a Teutila y es amado por Marina, quien a su vez intenta seducir a Xicoténcatl.

\section{1}

Este aspecto me impide estar totalmente de acuerdo con la tesis de González Acosta sobre la 'paternidad' de la obra: José Maria Heredia era católico observante y siempre defendió la misión evangelizadora de la Conquista.

\section{2}

La publicación en Filadelfia deja suponer que su autor viviera algún tiempo en Estados Unidos.

Tres novelas para la misma historia: el encuentro entre Cortés y Xicoténcatl

ROSA MARIA GRILLO
Borgia, estaba inconscientemente duplicando su trayectoria» ${ }^{38}$. Xicoténcatl el Viejo pone al descubierto las verdaderas intenciones de Cortés, intuyendo detrás de su «benignidad» una «hipocresía atroz y abominable». Imagina así un posible pensamiento de Cortés, en que el discurso historiográfico (las palabras referidas en las crónicas) no coincide con el discurso ficcional (el pensamiento): $«$ Mi soberana benignidad os reserva el alto honor que seáis mis aliados, para que perezcáis peleando contra mis enemigos» (pág. 92).

En este texto encontramos, atribuida a un héroe indígena, la misma problemática de tanta narrativa romántica europea de choque entre las razones del corazón y las del Estado -otra manera de borrar las diferencias entre Europa y América-, resueltas naturalmente a favor de este último, con tanta fuerza que se puede ver a Xicoténcatl como «uno de los precursores del sentimiento de nacionalidad mexicana» ${ }^{39}$. Tan opuestas son las exigencias del Estado y las del corazón ${ }^{40}$ que se llega casi a un desdoblamiento de la personalidad: en los diálogos entre Cortés y Xicoténcatl ambos modifican su postura frente al otro, según se trate de asuntos públicos o privados. Mientras que el joven americano, si bien distinguiendo abiertamente entre la obediencia a las decisiones del Senado que lo obligan a la paz y el abierto desprecio hacia el hombre Cortés, sigue portándose rectamente «sin variar nada en su noble franqueza» (pág. 113), en cambio Cortés, «apenas estuvieron solos, cambió de repente su expresivo y afectuoso semblante en un continente frío y seco" hasta llegar al conflicto directo que ocasiona la terrible amenaza del héroe indígena: «después que la paz esté ratificada, el general de Tlaxcala respetará al capitán de los extranjeros y Xicoténcatl te buscará y pedirá razón» (pág. 113).

Hay también otro carácter que nos permite hablar de discurso poscolonial que rechaza de la Conquista hasta la misión evangelizado$\mathrm{ra}^{41}$ : una postura anticatólica y no sólo anticlerical como será en tanta narrativa posterior (La novia del hereje, de Vicente Fidel López), evidente ya en los primeros diálogos entre Fray Bartolomé de Oviedo y Teutila, la novia de Xicoténcatl, atraída con el engaño en el campo de Cortés:

¡Hipócritas! Estáis llenos de vicios abominables, iy osáis suponeros los ministros de un Dios! No sé si el vuestro será algún ser tan maléfico y malvado que merezca semejantes adoradores; pero estoy segura que sois los verdaderos enemigos del que gobierna el mundo, porque éste es bueno por su naturaleza.

A la afirmación de fray Bartolomé que Dios le envía aflicciones "para probar [su] paciencia y [su] sumisión a sus inmutables decretos», la respuesta es inmediata y no atañe sólo a la práctica religiosa sino a la esencia misma del catolicismo:

¿Un Dios complacerse en mi mortificación sólo por la curiosidad de saber si soy yo sufrida! Si es el que gobierna el mundo, ¿qué necesidad tiene de pruebas para conocer una de sus ínfimas partes? ¿Ni qué le importa a su grandeza que yo me conforme o no con sus decretos, que tú mismo llamas inmutables? Yo recurro a Dios en mi aflicción, sí, y recurro con fervor; pero es para bendecir su justicia y para consolarme contemplando sus justas venganzas porque, si hay monstruos como vosotros, preciso es que haya quien castigue vuestros crímenes (págs. 106-107).

El anónimo texto de Xicoténcatl, quizás por la proximidad cronológica a la Independencia que hacía más violento el sentimiento antiespañol, por la influencia del protestantismo anglosajón ${ }^{42}$, por la situación de un México mestizo orgulloso de su procedencia indígena, seguramente por una particular circunstancia vital e histórica de su autor que el anonimato nos esconde pero que de algún modo indirectamente confirma, queda como un eslabón indispensable en el proceso descolonizador emprendido por la novela histórica en el siglo XIX: pero no por casualidad es casi desconocido y sólo muy recientemente ha sido estudiado con detenimiento, precisamente porque enturbia y estorba el proceso de construcción de una identidad mexicana perseguida a través de la aceptación de la Conquista como obra de civilización, y de crítica a sus modalidades violentas y a las consecuencias en la época colonial. Esta identidad se ha impuesto en la literatura y en la historiografía gracias también a los otros textos sobre los mismos acontecimientos que vamos a analizar.

Me refiero, siempre quedando ceñida a la literatura americana del siglo XIX sobre la relación Xicoténcatl-Cortés, al breve relato $X i$ coténcatl de Vicente Riva Palacio (1832- 
1896), y a la novela Los mártires del Anábuac de Eligio Ancona (1835-1893), ambos mexicanos, militares y de probada fe republicana y liberal.

El primero, considerado el iniciador del cuento mexicano moderno, autor de novelas que recrean el clima y los sucesos de la época virreinal, presenta en este cuento la síntesis del proyecto integracionista de la identidad mexicana enalteciendo el doble origen de la población y reservando para las dos partes igual dosis de admiración. Pero analizando más atentamente el texto, nos damos cuenta del profundo eurocentrismo que lo anima tanto por el reconocimiento de la superioridad cultural española y de la ineluctable fuerza del progreso, como por la utilización léxica que reserva el campo semántico de la fuerza física y del coraje al campo tlaxcalteca («soberbio», «indómito», «invencible», «indomable», «belicoso»), y el campo semántico de lo racional y de la voluntad al ejército invasor («creer», «fingir», "comprender»). No se trata de una novela histórica sino, como hemos dicho, de un relato ceñido alrededor de las relaciones Cortés-Xicoténcatl, en el que falta totalmente la vida familiar a la que aludía Vicente Fidel López como llave para resaltar una u otra interpretación de la Historia. Y falta también la contraposición típica de la novela histórica entre el Bien y el Mal, el héroe y el antihéroe, como señalando la fatalidad de la Historia y una dignidad y un valor equivalentes en ambos bandos. Pero igualmente, y a pesar de una escritura cercana al 'grado cero' del discurso historiográfico, aparentemente inocente y objetiva, se insinúa el discurso hegemónico claro ya en el hecho mismo que no se mencionan nunca a los españoles como invasores y a los tlaxcaltecas como víctimas inculpables de la violencia ajena. Otros datos dignos de interés son la presencia de un traidor en las huestes tlaxcaltecas, indicado como la causa principal de la derrota, y la total aceptación y acentuación de los caracteres positivos de Cortés presentes en las crónicas, juzgando muchos de sus actos como expresión de generosidad y no de cálculos estratégicos: «Sin embargo, el general español quiso probar aún la benignidad y los medios de conciliación, enviando nuevos embajadores a proponer a Xicoténcatl un armisticio ${ }^{43}$. Siempre a la generosidad de Cortés se atribuye su intervención en el Senado de Tlaxcala: «el espíritu grande de Hernán Cor- tés sintió lo profundamente ingrato de la conducta del senado, e interpuso su valimiento para que Xicoténcatl fuese restituido a sus honores» (págs. 15-16). Pero a la desaparición de Xicoténcatl («según la opinión general, aquella separación era provenida del mal trato que los españoles daban a sus aliados, y sobre todo del odio que Xicoténcatl profesaba a esta alianza», pág. 16) sin otras explicaciones o comentarios, el héroe que «no sabía temblar ante la muerte» (pág. 16) viene condenado a muerte y ajusticiado. Las frases finales, que podrían aparecer como un tributo póstumo a una víctima inocente, revelan, según me parece, simplemente una afirmación del mito del buen salvaje a la vez que un grito de dolor por la realidad contemporánea mexicana, muy lejana de cualquier solución pacífica y liberal:

El caudillo de Tlaxcala, el héroe de la independencia de aquella República, espiraba suspendido de una horca, al pie de la cual los soldados de Cortés le contemplaban con admiración. A lo lejos, algunos Tlaxcaltecas huían espantados, porque aquel era el patíbulo de la libertad de una nación (pág. 17).

En Los mártires del Anábuac, que abarca toda la conquista de México con un epílogo que da cuenta de la desgracia política en la que incurrió Cortés por su arrogancia y ambición, el héroe protagonista no es Xicoténcatl sino Tízoc, un joven azteca de origen misterioso, amante de la hija de Moctezuma, que tiene el papel narrativo de hacer de puente entre las diversas realidades indígenas y los diversos momentos de la conquista: decidido a combatir a los extranjeros, abandona el templo donde estaba educándose a la vida religiosa y ofrece su brazo a Xicoténcatl; firmada la paz entre Tlaxcala y Cortés, vuelve a Tenochtitlan incitando a Cuauhtemotzin a la guerra y finalmente se bate con él hasta la derrota final. Eligiendo a un héroe ficcional, Eligio Ancona con mucha libertad puede entramar una historia familiar ${ }^{44}$ llena de intrigas, y siguiendo los movimientos de su héroe puede moverse en los diversos campos y situaciones: como indica el título, al héroe individual de los otros textos examinados le ha sustituido más que una etnia o una raza, una entera categoría histórica que por lo tanto no podía encarnarse en un personaje fuertemente connotado étnicamente, sino en alguien
43

Vicente Riva Palacio, Xicoténcatl, en Tres episodios mexicanos $y$ Siluetas de la Lotería Nacional de México, México, Ed. Lotería Nacional, 1947, pág. 12.

44

Como en la novela de 1826, Cortés apresa y viola a la amada del héroe, Gelitzi, hija de Moctezuma.
Tres novelas para la misma historia: el encuentro entre Cortés y Xicoténcatl ROSA MARIA GRILLO 
Antonio Castro Leal, «Prólogo» a Eligio Ancona, Los mártires del Anáhuac, en La novela del México colonial, I, cit., pág. 410.
Tres novelas para la misma historia: el encuentro entre Cortés y Xicoténcatl

ROSA MARIA GRILLO que por su misma vida -como la Malinche, Tízoc era hijo de un príncipe derrotado por Moctezuma y fue educado en el Colegio Mayor de Tenochtitlan- podía representar a todos los mártires del valle de México. Y como explica Antonio Castro Leal, los 'mártires' a los que alude el título son «todos los que sufrieron el ataque y la dominación de los españoles [...] pero lo son principalmente todos los que fueron víctimas de crueldades innecesarias, de injusticias sin nombre, de violencias injustificadas, que vieron destruidos algo más precioso que la vida, los sentimientos que son la base misma de la existencia humana» ${ }^{45}$. Este comentario de Castro Leal nos revela el discurso que rige la novela: mártires 'a priori' de una injusticia histórica -la invasión- pero sobre todo de las modalidades violentas -innecesarias, injustificadas-con las que fue actuada.

El narrador se mueve con gran agilidad mostrándonos ambas perspectivas ya desde el incipit: los indígenas agolpados en la playa vieron

las naves cuya quilla cortaba tan fácilmente las inquietas aguas del golfo [y] les parecían de dimensiones extraordinarias; aquellas grandes mantas desplegadas al viento eran para ellos de un uso desconocido y la falta de remos les hacía suponer que esos inmensos monstruos marinos eran impelidos por alguna fuerza sobrenatural (págs. 411-412),

mientras Cortés viene dibujado ya con sus caracteres sobresalientes: «hombre extraordinario», «energía y firmeza de voluntad», «lo mucho que codiciaba el oro", "ambición", «astucia», «envidia» (págs. 412-413). En el desarrollo de las acciones, al contrario de Riva Palacio que parecía alabar a todo el mundo y juzgar la Conquista una guerra impuesta a inocentes contendientes heroicos por el hado y la ley del progreso, Ancona dispensa juicios negativos a jefes y simples soldados del uno y otro bando: Moctezuma es «el rey modesto [que] no tardó en convertirse en soberbio, el valiente guerrero en débil y fanático sacerdote y el monarca justiciero en déspota y tirano», pág. 442); Hernán Cortés «no sólo hacía comedias para los incultos americanos, sino que las preparaba también para los semicivilizados europeos [...] Hasta aquí, no había empleado más que la astucia. Más tarde le veremos emplear los grillos, la picota y la horca» (pág. 465); los totonacas «habían sacudido el yugo de Motecuzoma para caer en el yugo más ominoso todavía de los europeos» (pág. 468). Lo único que parece salvar son los conceptos abstractos: por un lado, afirma, «hubo algo que no pudo perecer entonces..., que no perecerá jamás: la sed de sangre de los conquistadores, la villanía del rey, el heroísmo de las víctimas» (pág. 525); "Los aztecas se defendían con heroísmo. La historia de la defensa de Tenochtitlan es una epopeya en que se encuentran hazañas dignas de ser cantadas por Homero» (pág. 615); por el otro, no hay dudas acerca de la misión evangelizadora de los españoles ( ¿ ¿Cómo no había de creer Hernán Cortés en un milagro de la Providencia cuando veía sus filas aumentadas por los que debían diezmarlas?», pág. 483), tanto más necesaria en aquellas tierras donde se perpetraban sacrificios humanos:

Entonces cuatro de aquellos infames ministros de Satanás sujetaron al niño por los brazos y las piernas; el quinto apretó su garganta con el círculo sagrado, y Tayatzín, el inmundo pontífice, levantó en alto su cuchilla de obsidiana (pág. 613).

Xicoténcatl, si bien no es el héroe designado por Ancona para asumir en sí el papel de héroe a tutto tondo a través de los elementos de su vida familiar e histórica, es el mismo héroe sin mancha que hemos visto en los demás textos, así como «el pueblo de Tlaxcala [...] sobrio, laborioso, indómito y amante, sobre todo, de su independencia y sus instituciones» (pág. 473), es el modelo de nación que hay que oponer al sistema colonial y al México independiente, ambos corruptos y violentos. Las dotes de Xicoténcatl se limitan al valor guerrero («indomable») y al respeto hacia las decisiones del Senado, pero esto ya es suficiente para oponerlo, en cuanto personaje histórico, a su enemigo Cortés: el general tlaxcalteca detenido por orden del senado «no tenía otro delito que amar demasiado a su patria y leer con más acierto en el porvenir que aquellos próceres, débiles y gastados»; la intercesión de Cortés para que le restituyeran el mando del ejército no responde, como en el cuento de Riva Palacio, a pura generosidad sino a un bien calculado proyecto:

Pronto saldrá conmigo a la guerra y yo encontraré entonces una ocasión para castigarle mejor que esos 
débiles senadores. ¡Meterle en una jaula cuando debía ya haber pagado en la horca sus imprudentes palabras! (págs. 598-599).

El narrador propone un modelo 'mestizo' condenando los excesos de ambos lados: una entidad -el valle del Anáhuac- audaz y valerosa, mal gobernada por su jefe y por los 'inmundos sacerdotes', tuvo que ser sacrificada para que se salvaran sus ánimas y pudiera nacer el nuevo México independiente, mestizo y católico, proyectado hacia un futuro finalmente libre de los excesos tanto de la barbarie pagana de los aztecas como de las violencias innecesarias y de la codicia de los españoles y de sus sacerdotes. En un paso central de la novela-después de una batalla con los tlaxcaltecas y antes de que Cortés se enfrentara con Narváez- se puede leer este mensaje esclarecedor:

De súbito una exclamación de alegría salió de los labios de todos. Acababan de descubrir en un claro del bosque una cruz rústica de madera que ellos mismos habían plantado allí después de la destrucción de los ídolos de Cempoala. 'Amigos míos', dijo Hernán Cortés, 'el cielo sin duda protege nuestra empresa puesto que hace salir a nuestro encuentro el signo santo de la redención. Y corriendo donde estaba la cruz se postró de hinojos ante su base de piedra. Todos los soldados se creyeron obligados a imitarle y se arrodillaron también. [...] El padre Olmedo, capellán del ejército, con voz robusta y sonora comenzó a recitar una oración que todos los circunstantes repitieron en coro. Entonces el sacerdote levantó el brazo y bendijo al ejército, invocando el santo nombre de Dios. $\mathrm{Al}$ ver a aquellos hombres arrodillados ante dos toscos pedazos de madera atados con mimbres, a ver a aquel sacerdote de venerable aspecto [...] un espectador cualquiera se hubiera creído transportado a los primitivos tiempos de la Iglesia en que los monasterios se elevaban en medio de los páramos. $\mathrm{Y}$, sin embargo, aquellos hombres que oraban así, aquellos hombres que eran absueltos por un sacerdote cristiano, habían saqueado pocos meses antes los tesoros de Motecuzoma, habían violado a las vírgenes del Anáhuac y habían manchado sus manos con la sangre de las víctimas indefensas en Cholula» (pág. 562).

Con repetidas invocaciones al valor de cruzada de la Conquista, pero condenando las 'violencias innecesarias' cometidas por su jefe y reconociendo la tarea justiciera de la Historia («Pero la historia no ha perdido todavía de vista esa aldehuela de Izancánac, donde el conquistador echó un sello a sus maldades con el atentado de este triple suplicio», pág. 623), se llega al final de la novela, que enseña a un Cortés envejecido, «lleno de tedio y de amargura»: «Lo habían matado los remordimientos, la contrariedad y el despecho [...] La ingratitud proverbial de los reyes vengaba hacia cierto punto la sangre de tantos mártires sacrificados a su ambición y crueldad» (pág. 624). Esta frase final cierra definitivamente el discurso de las reivindicaciones de los criollos contra la corona: en 1547 -año de la muerte de Cortés- como durante todo el periodo colonial, la 'ingratitud proverbial de los reyes' hacia sus hijos mejores había marcado negativamente las relaciones entre la madrepatria y sus tierras ultramarinas, motivando la justa rebelión de los patriotas americanos.

Efectivamente, si descolonizarse, nos lo enseña la historia reciente de la América central francófona y anglófona y de los países de Asia y África, significa antes que nada oponer a la voz de los colonizadores la voz de los colonizados que se adueñan finalmente de su pasado y de su Historia, en Latinoamérica este proceso inicia sólo ya avanzado el siglo XX como fruto no de una lucha de Independencia sino de la crisis de la Modernidad europea y de la toma de conciencia de la americanidad. La excentricidad de la historia de América ${ }^{46}$, y por lo tanto de su literatura, consiste en que las luchas de Independencia han sido una cuestión interna al sistema colonial -entre centro y subcentro, entre europeos y colonos, sin tocar la periferia indígena- una lucha de clase y no una guerra étnica, y por lo tanto un texto como el Xicoténcatl anónimo que condena la Conquista en sí y deja entrever la voz de los vencidos, si bien filtrada por la cultura europea, queda como indicio de una ocasión perdida: en efecto, la re-escritura de la Historia hecha por la mayoría de las novelas históricas del siglo XIX confirman la exclusión de la voz indígena en el proceso de la independencia y de la formación de la 'nación' y de la 'identidad'. Son los criollos los que han hecho la Historia y en el siglo XIX la re-escriben oponiendo su versión -siempre eurocéntrica, crítica hacia las modalidades degenerativas de la gestión española y no hacia el hecho en sía la oficialista del Imperio como lo confirman,

\section{6}

Desde una misma situación de poscolonialismo, las Américas anglosajona y latina han desarrollado Historias diferentes con éxitos opuestos: la primera, punta de diamante del Primer Mundo, la segunda aún ahora pedazo de un Tercer Mundo que se interroga sobre su identidad $e$ intenta descolonizarse económica y culturalmente.
Tres novelas para la misma historia: el encuentro entre Cortés y Xicoténcatl

ROSA MARÍA GRILLO 
En las dos novelas analizadas también la confrontación de otros personajes ta Malinche, Moctezuma, los demás jefes in dígenas y españoles- $y$ la interpretación de otros episodios -la noche triste, la batalla entre Cortés y Narváez- confirmarían la misma tesis que he intentado demostrar ciñéndome sólo al enfrentamiento Xicoténcatl-Cortés (en el relato de Riva Palacio por su brevedad quedan excluidos otros episodios de la Conquisto de México así como la vida familiar de los protagonistas). aunque con matices diferentes, el Xicoténcatl de Riva Palacio y Los mártires del Anábuac de Eligio Ancona ${ }^{47}$.

Paradójicamente, el anónimo Xicoténcatl, el texto más fiel a las fuentes hasta reproducir, entre comillas, enteros párrafos de Solís, es el que más revoluciona el discurso historiográfico oficial, proponiéndose como interesante anticipación del discurso poscolonial, del cual Hispanoamérica por las peculiaridades de su Historia parecería haberse autoexcluido. 